\title{
PERFORMA AYAM KAMPUNG SUPER YANG DIBERI TEPUNG USUS AYAM SEBAGAI SUBTITUSI TEPUNG IKAN
}

\author{
Performance of Super Native Chickens Given Chicken Intestine Meal \\ as Fish Meal Substitute \\ Yahya Ismail, *Syahruddin, dan Srisukmawati Zainudin \\ Jurusan Peternakan, Fakultas Pertanian, Universitas Negeri Gorontalo \\ *Coresponding Authors: email: syahrudin@ung.ac.id
}

\begin{abstract}
The aim of this research was to analyze the performance of the super native chicken and the optimal level of chicken intestine meal which can substitute fish meal in the feed ration. This study used a completely randomized design (CRD) consisting of 5 treatments and 4 replications. The treatments given were P0 $=10 \%$ fish meal $+0 \%$ chicken intestine meal in the feed rations, $\mathrm{P} 1=7.5 \%$ fish meal $+2.5 \%$ chicken intestine meal in the feed rations, $\mathrm{P} 2=5 \%$ fish meal $+5 \%$ chicken intestine meal in the feed rations, $\mathrm{P} 3=2.5 \%$ fish meal $+7.5 \%$ chicken intestine meal in the feed ration, $\mathrm{P} 4=0 \%$ fish meal $+10 \%$ chicken intestine meal in the feed ration. The number of super native chickens used in this study was 100 chickens. The results showed that giving chicken intestine meal as a substitute for fish meal in the feed ration had no significant effect $(\mathrm{P}>0.05)$ on feed ration consumption, body weight gain, and feed conversion ratio of super native chicken. It can be concluded that giving chicken intestine meal as a substitute for fish meal in the feed ration gives the same performance. Chicken intestine meal can substitute or replace fish meal up to a level of $10 \%$ in the feed ration super native chicken.
\end{abstract}

Keywords: Super native chicken, Performance, Fish meal, Chicken intestine meal

\begin{abstract}
ABSTRAK
Tujuan penelitian in untuk menganalisis performa ayam kampung super dan level optimal tepung usus ayam yang dapat mensubtitusi tepung ikan dalam ransum. Penelitian ini menggunakan rancangan acak lengkap (RAL) terdiri dari 5 perlakuan dan 4 ulangan. Perlakuan yang diberikan pada ayam kampung super yaitu: $\mathrm{P} 0=10 \%$ tepung ikan tepung usus ayam dalam ransum, $\mathrm{P} 1=7,5 \%$ tepung ikan $+2,5 \%$ tepung usus ayam dalam ransum, P2 $=5 \%$ tepung ikan $+5 \%$ tepung usus ayam dalam ransum, $\mathrm{P} 3=2,5 \%$ tepung ikan $+7,5 \%$ tepung usus ayam dalam ransum, $\mathrm{P} 4=0 \%$ tepung ikan $+10 \%$ tepung usus ayam dalam ransum. Jumlah ayam kampung super yang digunakan dalam penelitian ini sebanyak 100 ekor. Hasil penelitian menunjukkan bahwa pemberian tepung usus ayam sebagai substitusi tepung ikan dalam ransum tidak berpengaruh nyata $(\mathrm{P}>0,05)$ terhadap konsumsi ransum, pertambahan bobot badan, dan konversi ransum ayam kampung super. Dapat disimpulkan bahwa pemberian tepung usus ayam sebagai substitusi tepung ikan dalam ransum memberikan performa yang sama. Tepung usus ayam dapat mensubtitusi atau menggantikan tepung ikan sampai pada level 10\% dalam ransum ayam kampung super.
\end{abstract}

Kata Kunci : Ayam kampung super, Performa, Tepung ikan, Tepung usus ayam

Cara Mengutip (APA Citation Style)

Ismail, Y., Syahruddin, dan Zainudin, 2021. Performa Ayam Kampung Super Yang Diberi Tepung Usus Ayam Sebagai Subtitusi Tepung Ikan. Jambura Journal of Animal Science, 3(2), 120-128 
PENDAHULUAN

Perkembangan dalam bidang sektor peternakan di Indonesia saat ini sangatlah pesat, sejalan dengan meningkatnya kesadaran masyarakat akan pentingnya nilai gizi bersumber dari hewani, salah satunya berasal dari ternak ayam kampung jenis super. Usaha peternakan ayam kampung super sangat potensial untuk dikembangkan, ayam kampung super memiliki pertumbuhan dar reproduksi yang lebih cepat dibanding ayam kampung (buras) (Masili, dkk, 2018).

Peningkatan jumlah populasi dan tingkat produksi unggas perlu diimbangi dengan peningkatan ketersediaan pakan Untuk mendapatkan pertumbuhan ayam yang cepat dan produktifitas yang tinggi diperlukan pakan yang cukup mengandung zat-zat makanan yang dibutuhkan, baik secara kualitas maupun secara kuantitas. Zat-zat makanan tersebut seperti karbohidrat, protein, lemak, mineral, dan vitamin harus tersedia dalam ransum. Ketersediaan bahan pakan pada ternak merupakan salah satu faktor penting dalam keberhasilan usaha peternakan ayam kampung super, namun tingginya harga pakan komersil menyebabkan biaya yang dikeluarkan oleh para peternak menjadi tinggi, dan pakan yang mahal sangat membebani peternak. Harga pakan yang mahal dipengaruhi oleh bahan baku yang dibutuhkan belum mampu dikelola dengan baik sehingga kebanyakan pabrik pakan masih mengharapkan bahan baku pakan dari luar negeri seperti tepung ikan.

Tepung ikan merupakan salah satu bahan pakan sumber protein hewani yang biasa digunakan dalam ransum ternak unggas. Kebutuhan ternak unggas akan pakan sumber protein hewani sangat penting, karena memiliki kandungan protein relatif tinggi yang disusun oleh asam-asam amino esensial kompleks yang dapat mempengaruhi pertumbuhan sel-sel jaringan tubuh ternak. Kandungan nutrisi tepung ikan rucah dalam persen bobot kering yaitu protein kasar sebesar 58,97\%, lemak 6,54\%, abu $27,98 \%$, serat kasar 1,64\%,
BETN 4,85\% dan gross energi 2714,94 $\mathrm{kkal} / 100 \mathrm{~g}$ (Utomo et al., 2013). Kandungan protein tepung ikan dapat mempengaruhi kualitas protein dalam ransum ayam, sementara harga tepung ikan semakin tinggi. Hal ini disebabkan karena ikan yang dijadikan sebagai tepung ikan untuk ransum unggas, bersaing dengan kebutuhan manusia. Salah satu upaya yang dapat dilakukan untuk mengurangi atau mengganti penggunaan tepung ikan dalam ransum unggas, yaitu mencari bahan pakan alternatif untuk dijadikan sebagai bahan subtitusi dari tepung ikan. Bahan lokal yang diduga dapat digunakan untuk mengganti tepung ikan dalam ransum unggas adalah tepung usus ayam.

Usus ayam merupakan hasil limbah pemotongan ayam dan dapat menyebabkan bau atau pencemaran lingkungan dan mempunyai nilai yang rendah karena mudah rusak. Oleh karena itu, untuk mempertahankan limbah usus ayam agar supaya tidak cepat rusak, harus cepat dilakukan proses pengolahan untuk mendapatkan tepung usus ayam. Hal inilah yang menjadikan penulis tertarik untuk memanfaatkan tepung usus ayam sebagai bahan pakan alternatif untuk mensubtitusi atau menggantikan tepung ikan dalam ransum ternak ayam kampung super.

Ayam kampung super dalam pemeliharaannya membutuhkan pakan yang berkualitas untuk pemenuhan nutrisinya, sebab pakan yang sempurna dengan kandungan zat nutrisi yang seimbang akan memberikan hasil yang optimal. Sampai sekarang belum ada informasi tentang penggunaan tepung usus ayam broiler dalam ransum ayam kampung super.. Pemanfaatan bahan pakan alternatif ini khususnya diharapkan bisa meminimalisir biaya penyusunan ransum ternak ayam kampung super.

\section{METODE PENELITIAN}

Penelitian ini dilaksanakan pada bulan Juli sampai dengan bulan September 2020 bertempat di kandang percobaan 
Desa Mongolato Kecamatan Telaga Jaya Kabupaten Gorontalo.

Alat yang digunakan dalam penelitian ini adalah petak kandang, tempat pakan, tempat minum, alat gilingan daging manual, satu set alat pengukusan usus ayam, timbangan kasar, timbangan digital, alat tulis dan alat dokumentasi.

Bahan yang digunakan dalam penelitian ini adalah DOC (day old chicks) ayam kampung super, tepung usus ayam broiler, jagung kuning, dedak padi, tepung ikan, bungkil kedelei, top mix dan air minum.

Tepung usus ayam yang digunakan berasal dari usus ayam broiler yang diperoleh dari penjual daging ayam broiler di pasar sentral Kota Gorontalo. Usus ayam broiler yang diperoleh selanjutnya diolah secara mekanis untuk mendapatkan tepung usus ayam. Proses pembuatan tepung usus ayam broiler dapat dilihat pada
Gambar

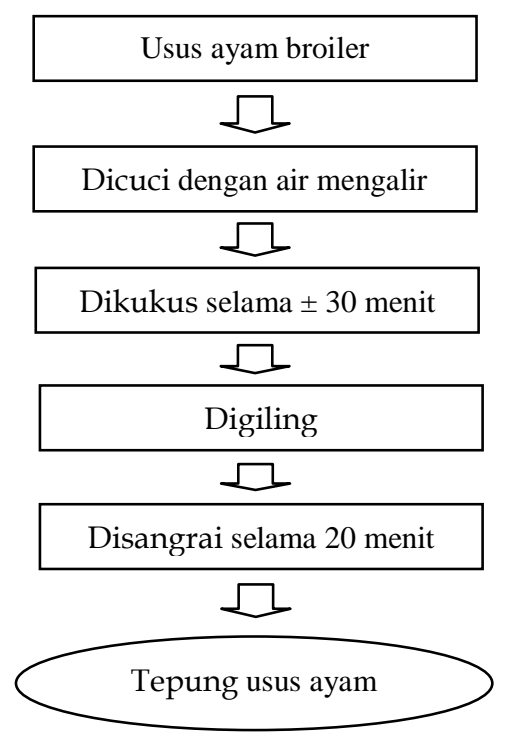

Gambar 1. Proses pembuatan usus ayam broiler menjadi tepung usus ayam

Rancangan penelitian yang matematika (Mattjik dan Sumertajaya, digunakan dalam penelitian adalah 2002; Syahruddin, dkk, 2020) adalah rancangan acak lengkap (RAL) terdiri dari sebagai berikut: 5 perlakuan dan 4 ulangan, dengan model

Keterangan:

$$
Y_{i j}=u+T_{i}+\epsilon_{i j}
$$

$Y_{i j}=$ Hasil pengamatan dari perlakuan ke-i dan ulangan ke-j

$u$ = Rata-rata pengamatan

$T_{i}=$ Pengaruh perlakuan ke-i $(\mathrm{i}=1,2,3,4,5)$

$\epsilon_{i j}=$ Pengaruh galat perlakuan ke-i dan ulangan ke-j $(j=1,2,3,4)$

Setiap ulangan menggunakan 5 anak ekor ayam, sehingga total ayam kampung super yang digunakan sebanyak 100 ekor. Perlakuan yang diterapkan dalam penelitian yaitu: $\mathrm{P} 0=10 \%$ tepung ikan tepung usus ayam dalam ransum, P1 $=7,5 \%$ tepung ikan $+2,5 \%$ tepung usus ayam dalam ransum, $\mathrm{P} 2=5 \%$ tepung ikan $+5 \%$ tepung usus ayam dalam ransum, P3 $=2,5 \%$ tepung ikan $+7,5 \%$ tepung usus ayam dalam ransum, $\mathrm{P} 4=0 \%$ tepung ikan $+10 \%$ tepung usus ayam dalam ransum.

Perlakuan yang diberikan yaitu substitusi tepung ikan dengan menggunakan tepung usus ayam. Komposisi bahan pakan dan kandungan nutrisi setiap perlakuan dalam penelitian disajikan pada Tabel 1.

Hasil analisis proksimat yang telah dilakukan di Laboraturium Kimia Makanan Ternak Jurusan Nutrisi dan 
Makanan Ternak, Fakultas Peternakan Universitas Hasanuddin (2020), menunjukkan bahwa kandungan nutrisi dari tepung usus ayam broiler adalah protein kasar 87,78\%, lemak kasar 18,36\%, serat kasar 1,12\%, BETN 1,07\%, kadar abu $0,64 \%$ dan gross energi $5.844 \mathrm{kkal} / \mathrm{kg}$.

Tabel 1. Komposisi ransum dan kandungan nutrisi setiap perlakuan

\begin{tabular}{|c|c|c|c|c|c|}
\hline \multirow{2}{*}{ Bahan Pakan } & \multicolumn{5}{|c|}{ Perlakuan (\%) } \\
\hline & P0 & P1 & P2 & P3 & P4 \\
\hline Jagung giling & 49 & 49 & 49 & 49 & 49 \\
\hline Dedak halus & 24 & 24 & 24 & 24 & 24 \\
\hline Tepung ikan & 10 & 7,5 & 5 & 2,5 & 0 \\
\hline Tepung usus ayam*) & 0 & 2,5 & 5 & 7,5 & 10 \\
\hline Bungkil kedelai & 15 & 15 & 15 & 15 & 15 \\
\hline Premiks (Top mix) & 2 & 2 & 2 & 2 & 2 \\
\hline Jumlah & 100 & 100 & 100 & 100 & 100 \\
\hline Komposisi nutrisi & P0 & P1 & P2 & P3 & $\mathrm{P} 4$ \\
\hline Energi Metab. (kkal/kg) & 3188,915 & 3208,5725 & 3228,23 & 3247,8875 & $\begin{array}{c}3267,5 \\
45\end{array}$ \\
\hline Protein kasar (\%) & 20,303 & 20,115 & 19,927 & 19,739 & 19,551 \\
\hline Lemak kasar (\%) & 6,84 & 7,0635 & 7,287 & 7,5105 & 7,734 \\
\hline Serat kasar (\%) & 5,805 & 6,041 & 6,277 & 6,513 & 6,749 \\
\hline $\mathrm{Ca}(\%)$ & 2,884 & 2,8105 & 2,737 & 2,6635 & 2,59 \\
\hline $\mathrm{P}(\%)$ & 1,1458 & 1,1538 & 1,1618 & 1,1698 & 1,1778 \\
\hline
\end{tabular}

Keterangan*) : Hasil analisis Laboratorium Kimia Makanan Ternak Jurusan Nutrisi dan Makanan Ternak Fakultas Peternakan Universitas Hasanuddin (2020).

Focus pengamatan performan dari ayam kampung super adalah: Pertambahan bobot badan, Konsumsi, dan konversi ransum.
Menghitung Pertambahan bobot badan, Konsumsi dan konversi ransum mengikuti saran Pakaya, dkk (2019); Dunggio, dkk, (2021)

$$
\begin{gathered}
\text { Konsumsi ransum }(\mathrm{g} / \text { ekor })=\text { Ransum yang diberikan }(\mathrm{g})-\text { Ransum sisa }(\mathrm{g}) \\
\text { Konversi ransum }=\quad \frac{\text { Jumlah konsumsi ransum }(\mathrm{g} / \text { ekor })}{\text { Pertambahan bobot badan }(\mathrm{g} / \text { ekor })}
\end{gathered}
$$

$$
\text { PBB }(g)=\text { BB akhir }(g)-\text { BB awal }(g)
$$

Keterangan :

PBB = Pertambahan bobot badan

$\mathrm{BB}$ akhir = Bobot badan akhir minggu

$\mathrm{BB}$ awal = bobot badan minggu sebelumnya

Data yang diperoleh dianalisis dengan analysis of variance berdasarkan rancangan acak lengkap (RAL), (Mattjik dan Sumertajaya, 2002).

\section{HASIL DAN PEMBAHASAN}

\section{Konsumsi ransum}

Hasil pengamatan dari rataan konsumsi ransum ayam kampung super yang diberi tepung usus ayam sebagai subtitusi tepung ikan dalam ransum disajikan pada Gambar 2.
Hasil analisis ragam menunjukkan bahwa pemberian tepung usus ayam sebagai substitusi tepung ikan dalam ransum tidak berbeda nyata $(\mathrm{P}>0,05)$ terhadap konsumsi ransum ayam kampung super. Hal ini berarti bahwa pemberian tepung usus ayam dalam ransum sampai taraf $10 \%$, memberikan konsumsi ransum yang sama dengan pemberian tepung ikan. Konsumsi ransum yang sama ini, diduga 
dipengaruhi oleh imbangan protein dan energi ransum semua perlakuan sudah sesuai dengan kebutuhan ayam kampung super. Kandungan protein dan energi metabolisme tepung usus ayam dan tepung ikan berimbang (hampir sama), sehingga menyebabkan kebutuhan nutrisi terpenuhi dan menyebabkan konsumsi ransum sama. Rataan konsumsi ransum ayam kampung super umur 0 - 8 minggu secara berturutturut adalah P0 (2998,4 g/ekor); P1 (3154,0 g/ekor); P2 (3119,2 g/ekor); P3 (3147,3 g/ekor); dan P4 (3189,9 g/ekor).

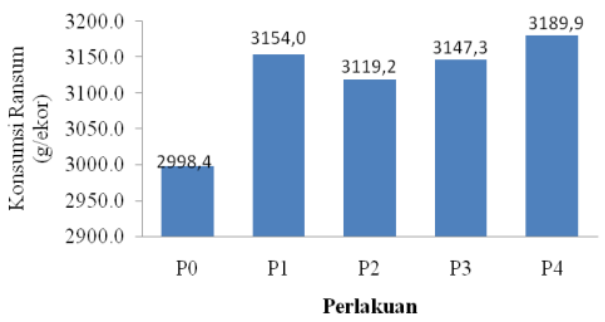

Gambar 2. Rataan konsumsi ransum ayam kampung super

Rataan konsumsi ransum ayam kampung super berkisar antara 2998,4 3189,9 (g/ekor) sampai pada umur 8 minggu atau 53,54 - 56,96 (g/ekor/hari). Konsumsi ransum hasil penelitian ini hampir sama dengan hasil penelitian Handoko (2011) bahwa jumlah konsumsi ransum ayam kampung super rata-rata 53,125 (g/ekor/hari), juga hasil penelitian Astuti (2012) bahwa jumlah konsumsi ransum ayam kampung antara 44,33-56,91 (g/ekor/hari). Demikian juga Sarwono (2011) bahwa jumlah konsumsi ransum ayam kampung super rata-rata 47,625 (g/ekor/hari) sampai pada umur 8 minggu.

Konsumsi dipengaruhi oleh kandungan energi (Prayogi, 2007). Jika kebutuhan energi telah terpenuhi maka ayam akan berhenti mengkonsumsi ransum. Kandungan energi metabolisme ransum penelitian berkisar antara 3.100 $3.200 \mathrm{kkal} / \mathrm{kg}$. Peningkatan level tepung usus ayam juga meningkatkan energi metabolisme ransum. Ternak akan mengkonsumsi pakan yang sesuai dengan batas kemampuan biologisnya sekalipun diberikan pakan yang berprotein tinggi. Menurut Fahrudin dkk. (2016) konsumsi ransum adalah jumlah makanan yang dikonsumsi oleh ternak untuk mencukupi hidup pokok dan produksi hewan tersebut. Selanjutnya Nuraini dkk. (2012) bahwa konsumsi pakan dipengaruhi oleh beberapa faktor antara lain: umur, palatabilitas ransum, kesehatan ternak, jenis ternak, aktivitas ternak, energi ransum, tingkat produksi, kuantitas dan kualitas ransum. Menurut Wahju (2004) menyatakan bahwa konsumsi ransum dipengaruhi oleh zat zat makanan yang terkandung dalam ransum.

\section{Pertambahan Bobot Badan}

Rataan hasil pengamatan dari pertambahan bobot badan ayam kampung super yang diberi tepung usus ayam sebagai subtitusi tepung ikan dalam ransum disajikan pada Gambar 3.

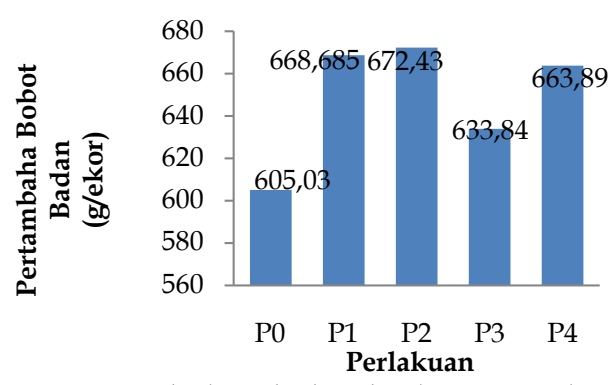

Gambar 3. Rataan pertambahan bobot badan ayam kampung super

Hasil analisis ragam menunjukkan bahwa pemberian tepung usus ayam sebagai substitusi tepung ikan dalam ransum tidak berbeda nyata $(\mathrm{P}>0,05)$ 
terhadap pertambahan bobot badan ayam kampung super. Ayam yang diberi ransum kontrol (P0) dan ransum perlakuan (P1, P2, P3, P4) menghasilkan pertambahan bobot badan yang sama besarnya. Kandungan protein tepung ikan dan tepung usus ayam hampir sama yang menyebabkan pertumbuhan ayam juga sama. Pertumbuhan bobot badan ayam sama juga dipengaruhi oleh konsumsi ransum yang tidak berbeda.

Rataan pertambahan bobot badan ayam kampung super masing-masing sebagai berikut: P0 $(605,03 \mathrm{~g} /$ ekor $) ; \mathrm{P} 1$ (668,68 g/ekor); P2 (668,68 g/ekor) P3 (633,84 g/ekor); P4 (663,89 g/ekor) sampai pada umur 8 minggu. Rataan pertambahan bobot badan yang sama menunjukkan bahwa tepung usus ayam dapat mensubtitusi atau menggantikan tepung ikan sampai pada level 10\% dalam ransum ayam kampung super. Peningkatan level tepung usus ayam dari 2,5 sampai $10 \%$ juga terlihat tidak menurunkan bobot badan ayam kampung super. Pertambahan bobot badan yang diperoleh lebih rendah dari hasil penelitian Widodo (2014) bahwa ayam kampung super yang diberi pakan komersial BR-1 dengan protein minimum $21 \%$ pertambahan berat badannya 873 g/ekor sampai masa panen (umur 60 hari). Demikian juga hasil penelitian Trisiwi (2016) bahwa pertambahan bobot badan mencapai 862,0 g/ekor.

Secara umum penambahan bobot badan akan dipengaruhi oleh jumlah konsumsi pakan yang dimakan dan kandungan nutrisi yang terdapat dalam pakan tersebut (Ichwan, 2003). Protein yang berkualitas baik akan meningkatkan pertambahan bobot badan setiap unit protein yang dikonsumsi (Sarwono, 2011).

\section{Konversi Ransum}

Rataan konversi ransum ayam kampung super yang diberi tepung usus ayam sebagai subtitusi tepung ikan dalam ransum disajikan pada Gambar 4.

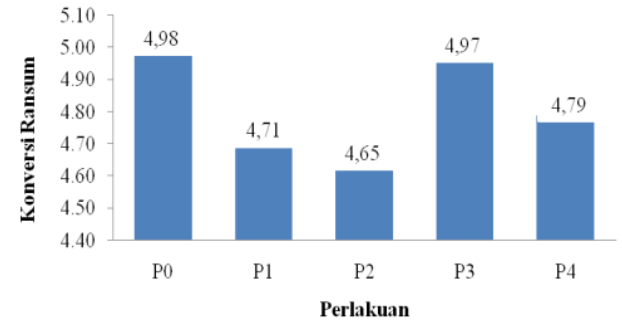

Gambar 4. Rataan konversi ransum ayam kampung super.

Hasil analisis ragam menunjukkan bahwa pemberian tepung usus ayam sebagai subtitusi tepung ikan dalam ransum tidak memberikan pengaruh yang nyata $(\mathrm{P}>0,05)$ terhadap konversi ransum ayam kampung super. Konversi pakan yang sama menunjukkan bahwa tepung usus ayam dapat mensubtitusi atau menggantikan sampai pada level 10\% tepung ikan dalam ransum ayam kampung super. Konversi ransum yang sama juga dipengaruhi oleh konsumsi ransum dan pertambahan bobot badan ayam yang sama antar perlakuan. Hal ini berarti bahwa ayam kampung super memiliki kemampuan fisiologis yang sama dalam memanfaatkan ransum. Rataan nilai konversi ransum ayam kampung super masing-masing sebagai berikut P0 $(4,98)$; P1 (4,71); P2 $(4,65) ;$ P3 $(4,97)$ dan P4 $(4,79)$ sampai pada umur 8 minggu. Hal ini menunjukkan bahwa untuk meningkatkan satu kilogram berat badan ayam kampung super dibutuhkan ransum sebanyak 4,65 $4,98 \mathrm{~kg}$. Hasil penelitian hampir sama dengan pernyataan Rasyaf (2013) bahwa konversi ransum ayam kampung umur 8 minggu menggunakan ransum yang kandungan proteinnya $17 \%$ konversi pakan yang diperoleh 4,32. Nilai konversi ransum yang diperoleh masih cukup tinggi dibandingkan dengan hasil penelitian Pakaya dkk. (2019) bahwa konversi ransum ayam kampung super yang diberi level penambahan tepung kulit kakao fermentasi dalam ransum berkisar antara 
2,58 - 3,24. Demikian juga Prabewi dkk. (2019) bahwa konversi ransum ayam kampung super yang diberi tambahan tepung keong mas sebanyak $20 \%$ sebagai pengganti konsentrat selama 78 hari sebesar 3,35.

Nilai konversi ransum yang rendah menunjukkan bahwa efesiensi penggunaan ransum yang baik, karena semakin efesien ayam mengonsumsi ransum untuk memproduksi daging (Allama et al., 2012). Pernyataan yang sama juga oleh Fahruddin dkk. (2016) bahwa semakin kecil nilai konversi pakan maka semakin efisien ternak tersebut mengkonversikan pakan ke dalam bentuk daging. Nilai konversi ransum dipengaruhi oleh beberapa faktor seperti bangsa, umur ternak, kandungan nutrisi ransum, tatalaksana, penggunaan bibit yang baik, keadaan temperatur dan keadaan ternak.

\section{Pertumbuhan Mingguan}

Hasil pengamatan dari rataan pertumbuhan mingguan ayam kampung super yang diberi tepung usus ayam sebagai subtitusi tepung ikan dalam ransum disajikan pada Gambar 5.

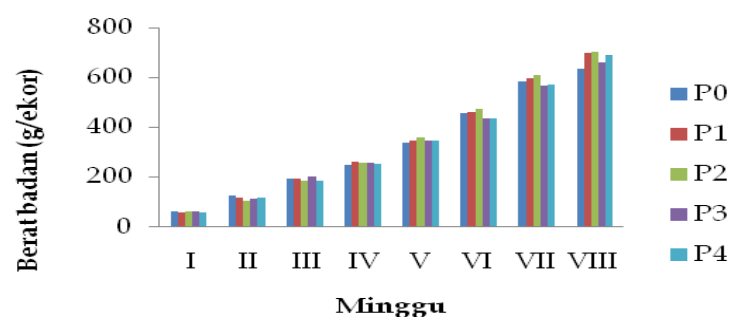

Gambar 5. Rataan pertumbuhan ayam kampung super umur 1-8 minggu setiap perlakuan

Gambar 5. menunjukkan bahwa nilai pertumbuhan ayam kampung super pada minggu pertama masih rendah. Hal ini terjadi karena pada minggu pertama pemeliharaan hipertrofi sel belum maksimal sehingga tidak berdampak pada berat badan, minggu terakhir pemeliharaan pada masa pertumbuhan hipertrofi sel semakin tinggi (Syahruddin et al., 2018) sehingga berdampak pada berat badan yang lebih tinggi. Nilai pertumbuhan ayam kampung super pada minggu pertama sampai minggu ke delapan meningkat kisaran dari 75 sampai $85 \mathrm{~g} /$ ekor/minggu. Hal ini menunjukkan bahwa pertumbuhan mingguan pada ayam kampung super yang diberi tepung usus ayam sebagai subtitusi tepung ikan dalam ransum, memiliki pertumbuhan yang sama setiap perlakuan pada tiap-tiap minggu. Hal ini menunjukkan bahwa tepung usus ayam broiler dapat menggantikan sebagian atau seluruh $(2,5$ $10 \%$ ) tepung ikan dalam ransum ayam kampung super yang berdampak pada pertumbuhan mingguan yang sama untuk semua perlakuan., selain dipengaruhi oleh pakan, pertumbuhan ayam kampung super juga dipengaruhi oleh faktor genetik dan lingkungan, hal ini sesuai dengan pernyataan Kurnia (2011), Saleh, (2020), Dako, dkk (2020) yang menyatakan bahwa faktor genetik dan lingkungan mempengaruhi laju pertumbuhan bobot badan ayam, Keseimbangan genetic yang belu optimal, dan juga dipengaruhi oleh mutu ransum dan tatalaksana pemeliharaan yang baik. Penyebab lamanya masa pemeliharaan ayam kampung super yang dilakukan oleh peternak pada umumnya disebabkan dari faktor genetik yang berupa penggunaan bibit yang kurang baik dan tidak adanya pelaksanaan program seleksi, sedangkan dari faktor lingkungan yang berupa penetapan manajemen pemeliharan belum terpadu dan juga belum sepenuhnya menetapkan teknologi pakan serta lemahnya pengendalian penyakit (Yaman et al., 2008).

\section{KESIMPULAN}

Berdasarkan hasil penelitian maka dapat disimpulkan bahwa pemberian tepung usus ayam sebagai substitusi tepung ikan dalam ransum memberikan performa yang sama. Tepung usus ayam dapat mensubtitusi atau menggantikan 
tepung ikan sampai pada level 10\% dalam ransum ayam kampung super.

\section{UCAPAN TERIMA KASIH}

Ucapkan terimakasih kepada

Dekan Fakultas Pertanian Universitas

\section{DAFTAR PUSTAKA}

Allama, H., Sofyan, O., Widodo, E., dan Prayogi, H.S. (2012). Pengaruh penggunaan tepung ulat kandang (Alphitobius diaperinus) dalam pakan terhadap penampilan produksi ayam pedaging. Jurnal Ilmu-Ilmu Peternakan, 22(3), 1-8.

Astuti, N. (2012). Kinerja Ayam Kampung dengan Ransum Berbasis Konsentrat Broiler Univ. Mercu Buana Yogyakarta. Jurnal Agrisains. Vol. 4 (5).

Fahruddin, A., Tanwirah, W., Indrijani, H. (2016). Konsumsi ransum, pertambahan bobot badan dan konversi ransum ayam lokal di Jimmy's Farm Cipanas Kabupaten Cianjur. Fakultas Peternakan, Universitas Padjadjaran.

Handoko. (2011). Beternak Ayam Kampung. Data Publishing Surabaya.

Dako, S. (2019). Crossbreding Between Native Chiken And Leghorn Chiken Strain Isa Brown. Jurnal Peternakan, 16(1), 1-9.

Ichwan. (2003). Membuat pakan ras pedaging. Agro Media Pustaka, Tangerang.

Kurnia, Y. (2011). Morfometrik Ayam Sentul, Kampung dan Kedu Pada Fase Pertumbuhan dari Umur 1-12 Minggu. (Skripsi). Fakultas Peternakan Institut Pertanian, Bogor.

Mattjik, A. A. \& Sumertajaya, I. M. (2002). Perancangan Percobaan . Jilid I Ed ke2. IPB Press, Bogor.
Negeri Gorontalo, Dalam pendanaan kegiatan penelitian ini melalui Dana PNBP Fakultas Pertanian dalam skim Penelitian Kolaboratif Tahun anggaran 2019-2020.

Masili, S., Dako, S., Ilham, F., \& Gubali, I. S. (2018). Heritabilitas Bobot Telur, Bobot Tetas Dan Bobot Badan Ayam Hasil Persilangan Umur 1 Minggu (DOC). Jambura Journal of Animal Science, 1(1), 1-5.

Nuraini, Sabrina \& Latif, S. A. (2012). Fermented product by Monacus purpureus in poultry diet effects on laying performance and egg quality. Pakistan Journal of Nutrition. 11, 507510.

Pakaya, S. A. (2019). Performa Ayam Kampung Super Yang Di Beri Level Penambahan Tepung Kulit Kakao (Theobroma cacao, L.) Fermentasi Dalam Ransum. Jambura Journal of Animal Science, 1(2), 40-45.

Prabewi, N., Kurniawan, F., Suharti, S., Yulianti, L., \& Hafid, Z. (2019). Pengaruh Tepung Keong Mas (Pomacea canaliticulata) Dalam Campuran Pakan Sebagai Pengganti Konsentrat Terhadap Performa Ayam Kampung Super. Jurnal Penelitian Peternakan Terpadu, 1(1), 32-43.

Prayogi, H.S. (2007). Pengaruh penggunaan minyak kelapa dalam ransum terhadap konsumsi pakan, peningkatan bobot badan, konversi pakan, dan karkas broiler periode finisher. Jurnal Ternak Tropika 7(2), 18 $-27$.

Rasyaf, M. (2013). Beternak Ayam Kampung. Cetakan ke III , Penebar Swadaya, Jakarta.

Sarwono, B. (2011). Beternak Ayam Buras, Cetakan 33, Penebar Swadaya. Jakarta. 
Syahruddin, Agustina, L., Pakiding, W. \& Malaka, R. (2018). Supplementation of L-Arginine through the Parent Feed and in Ovo Feeding on Post-hatch Performances of Local Ducks. International Journal of Sciences: Basic and Applied Research (IJSBAR), 40(2), 87-98.

Syahruddin, S., Nahrowi, N., \& Yatno, Y. (2020). Kemampuan Polisakarida Mannan Sebagai Oral Adjuvan Vaksin Avian Influenza Pada Ayam Broiler. Jambura Journal of Animal Science, 2(2), 90-101.

Trisiwi, H.F. (2016). Pengaruh level protein pakan yang berbeda pada masa starter terhadap penampilan Ayam Kampung Super. Jurnal Ilmiah Peternakan Terpadu, $4(3)$.

Saleh, U. (2020). Keseimbangan Genetik Eksternal pada Ayam Hasil Silangan. Jambura Journal of Animal Science, 2(2), 76-89.
Dako, S., Ilham, F., Laya, N. K., \& Yusuf, M. F. (2020). Nheritance of External Genetic Characteristics In Chicken Through Triple Crossing Model. International Journal of Advanced Science and Technology, 29(9s), 549558.

Utomo, N.B.P, Susan, Setiawati, M. (2013). Peran tepung ikan dari berbagai bahan baku terhadap pertumbuhan lele sangkuriang Claris sp. Jurnal Akuakultur Indonesia, 12(2), 158-168.

Wahju, J. (2004). Ilmu Nutrisi Unggas. Universitas Gajah Mada Press, Yogyakarta.

Widodo, J. (2014). Bibit Ayam Kampung Super. http://jackjogja.blogspot.com/.

Yaman, M.A, Zulfan \& Dasrul. (2008). Pengembangan metode seleksi potensi genetik dan pendekatan nutrisi untuk menghasilkan induk ayam buras pedaging unggul. Laporan Penelitian Hibah Kompetensi-Dikti, Jakarta. 